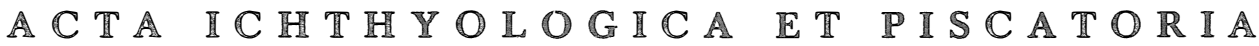 Vol. IX Fasc. 1

Krzysztof ZDZITOWIECKI

Parasitology

\section{DIGENETIC TREMATODES IN ALIMENTARY TRACTS OF FISHES OF SOUTH GEORGIA AND SOUTH SHETLANDS (ANTARCTICA)}

\section{PRZYWRY Z PRZEWODU PORARMOWEGO RYB Z OROLIC POZUDNIOWEJ GEORGII I POEUDNIOWYCH SZETLANDÓW (ANTARKTYKA)}

Research Centre of Parasitology, Polish Academy of Sciences, Warszawa

Digenetic trematodes were found in 30 fish individuals out of 46 examined from catches obtained off South Shetlands, while off South Georgia all 16 individuals examined were found to contain the parasites. The same 7 parasitic species were found in the two areas, Elytrophalloides oatesi (Leiper et Atkinson, 191.4) prevailing off South Georgia and Plagioporus pennelli (Leiper et Atkinson, 1914) and Genolinea bowersi (Leiper et A tkinson, 1914) off South Shetlands. The remaining species included: Lecithaster australis Prudhoe et Bray, 1973; Gonocerca phycidis Manter, 1925; Lepidapedon antarcticus Byrd, 1963; and Neolebouria georgiensis Gibson, 1976. The descriptions of L. antarcticus, L. australis and $G$. bowersi are given along with a number of supplementary remarks concerning morphology of the remaining species found.

\section{INTRODUCTION}

The trematodes dealt with herein were collected by the author during the Polish Academy of Sciences' Antarctic Expedition, within the period of February - April 1977. 
The complete list of hosts examine: was published elsewhere (Zdzitowiecki, 1978). Off South Shetlands, 30 fish individuals $(65 \%)$ out of 46 examined were fornd to contain trematodes, whereas all the 16 fishes examined of South Georgia were infested. The total number of 3471 trematode individuals belonging to 7 species were collected. Previons reports record 7 species off South Georgia (Rovaleva and Gaevskaya, 1974; Gibson, 1976) and 6 species off South Shetlands (Szidat and Graefe, 1957; Gibson, 1976).

\section{METHODS}

Iiving trematodes removed from fish alimentary tracts were placed in fresh wate For $1-2$ hours, after which time those still alive were killed by heniting the water. The animals were fixed in $75 \%$ ethyl alcohol, shined wh alum carmine, alcohol-delydrated, and mounte in creosote by gradually evaporating alcohol from the creosote-alcohol mixture (1:4 origingi ratio). Pemanent mounting in Cana a balsam proved unsucossful, morphology of trematodes was therefore examined on terpporany creosote mounts. No pressure was applied to flatten the trematodes.

\section{DESCRIPTIONS}

Plagioporus pennelli (Leiper et Atkinson, 191A)

Synonyms: Podocotyle pennelli Leiper et Arthinson, 1914; Plagioporus pennelli georgianis Kovaleva et Gaevskaya, 1974.

Hosts and invasion intensity: see Table 1. The maximum intersity found was 105 individuals (in Notorhenia corriceps neglecta). Pleurogranma antarctica and Chaenocephalus aceratus are new hosts.

Location: iypical for the P. pennelli location are pyloric caeca and, frequently, anterior part of omall intestine, only 2 individuals being revealed in its posteriot part and 1 in large intestine.

Adult parasites were being found throughous the period of study, i.e., from February through April 1977.

Number of individuals examined: 669.

Remarks. Morphology and size of the trematodes correspond to the data found in literature (Leiper and Akinson, 1914, 1915; Byd, 1963; Gibson, 1976; and others). Gonads most frequently form a compact group, vitellaria covering the entire dorsal and lateral parts of the body. Some individuals show their gonads set more or less far apart. In many, vitellaria are less well-developed, sometimes giving the impression of being divided into 2-3 zones, with loosely-packed vesicles. In view of an extensive variability of those characters, the author sees no grounds for separating a subspecies, $P$. pennelli georgianus. The author's collection includes individuals identical with or to a varying degree approaching the subspecies description given by Kovaleva and Gaevskaya (1974).

A certain variability in the range of bursa cirri was found. Its proximal end is usually situated dorsally relative to the ventral sucker centre; some individuals, however, show a more posterior location, sometimes even beyond the posterior edge of ventral sucker. 
Occurrence of trematodes off South Shetlands and South Georgia

\begin{tabular}{|c|c|c|c|c|c|c|c|c|c|}
\hline \multirow{2}{*}{ Area } & \multirow{2}{*}{ Host } & \multirow{2}{*}{ Examined } & \multicolumn{7}{|c|}{ Infested (mean intensity) with } \\
\hline & & & $\begin{array}{l}\text { P. pen- } \\
\text { nelii }\end{array}$ & $\begin{array}{l}\begin{array}{l}\text { N. geor- } \\
\text { giensis }\end{array} \\
\end{array}$ & $\begin{array}{c}\text { L. antar- } \\
\text { cticus }\end{array}$ & E. oatesi & $\begin{array}{l}\text { L. aus } \\
\text { tralis }\end{array}$ & $\begin{array}{c}\text { G. bower } \\
\text { si }\end{array}$ & $\begin{array}{l}\text { G. phy- } \\
\text { cidis }\end{array}$ \\
\hline \multirow{8}{*}{ 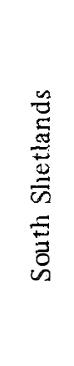 } & Notothenia corriceps neglecta Nybelin, 1951 & 11 & $11(37)$ & - & $1(1)$ & $2(1)$ & $1(1)$ & $8(19)$ & - \\
\hline & Notothenia rossi marmorata Fischer, 1885 & 11 & $11(21)$ & - & $2(1)$ & $1(19)$ & $1(1)$ & $7(18)$ & - \\
\hline & Nctothenia gibberifrons Lönnberg, 1905 & 9 & - & - & $1(1)$ & - & - & $1(1)$ & - \\
\hline & Notothenia nudifrons Lönuberg, 1905 & 5 & - & - & - & -- & - & $1(1)$ & _- \\
\hline & Trematomus bernacchii Boulenger, 1902 & 3 & $1(1)$ & - & - & - &. & $1(9)$ & - \\
\hline & Pleurogramma antarciica Boulenger, 1902 & 2 & $1(2)$ & - & - & - & -- & $1(7)$ & - \\
\hline & Chaenocephalus aceratus (Lönnberg, 1906) & 3 & $1(4)$ & $1(1)$ & - & $2(4)$ & $1(1)$ & $2(18)$ & 1. (2) \\
\hline & Total & 44 & $25(26)$ & $1(1)$ & $4(1)$ & $5(6)$ & $3(1)$ & $21(16)$ & $1(2)$ \\
\hline \multirow{7}{*}{ 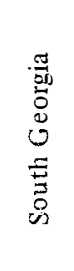 } & Notothenia rossi marmorata Fischer, 1885 & 5 & $4(8)$ & -- & $1(12)$ & $5(82)$ & $2(7)$ & $5(17)$ & - \\
\hline & Notothenia gibberifrons Lönnberg, 1905 & 1 & - & - & - & $1(4)$ & - & - & - \\
\hline & Trematomus hansoni Boulenger, 1902 & 1 & _- & _ & - & $1(67)$ & - & _- & _- \\
\hline & Parachaerichthys georgianus (Fischer, 1885) & 2 & - & $2(2)$ & - & $2(19)$ & - & $1(4)$ & $1(1)$ \\
\hline & Chaenocephalus aceratus (Lönnberg, 1906) & 3 & - & $3(5)$ & - & $3(38)$ & $1(2)$ & - & $3(2)$ \\
\hline & Champsocephalus gunnari Lönnberg, 1905 & 1 & - & - & - & $1(20)$ & - & - & - \\
\hline & Pseudochaenichthys georgianus Norman, 1937 & 3 & -- & $3(7)$ & - & $3(533)$ & $1(\mathrm{i})$ & - & $3(5)$ \\
\hline & Total & 16 & $4(8)$ & $8(5)$ & $1(12)$ & $16(141)$ & $6(15)$ & $4(4)$ & $7(3)$ \\
\hline
\end{tabular}


All the hitherto-available data on the species were collected in the Antarctica: in most subcontinental provinces (Leiper and Atkinson, 1914, 1915; Byrd, 1963; Szidat, 1965; Prudhoe and Bray, 1973, Gibson, 1976) and off South Shetlands (Szidat and Graefe, 1967). Additionally, the species was recorded in the South Georgia province (Kovaleva and Gaevskaya, 1974; Gibson, 1976). The final hosts are the Notothenioidei, mainly the family Nototheniidae, and also Zoarcidae.

Neolebouria georgiensis Gibson, 1976

Hosts and invasion intensity: see Table 1. The maximum intensity recorded was 13 individuals (in Pseudochaenichthys georgianus). Ps. georgianus is a newly-found host. Location: entire length of intestine from pyloric caeca to large intestine, one individual being found in stomach.

Dates of findings: March 24, 1977 (off South Shetlands); April 1-4, 1977 (off South Georgia).

Number of individuals examined: 39 .

Remarks. Morphology of the material on hand is in complete accordance with the original description (Gibson, 1976). Egg dimensions show a somewhat larger variability range: $0.087-0.106 \times 0.039-0.054 \mathrm{~mm}$.

Gibson (1976) described the trematodes in fishes caught off South Georgia. An individual found by the present author in Chaenocephalus aceratus off South Shetlands is the first to be found in the subcontinental province. However, the species seems to be mainly characteristic of the South Georgia province. The hosts known so far are restricted to three species of the Bathydraconidae and Chaenichthyidae

\section{Lepidapedon antarcticus Byrd, 1963}

Synonyms: Lepocreadium trullaeforme Linton, 1940 sensu Szidat (1965) and Szidat and Graefe (1967) nec sensu Linton (1940).

Hosts and invasion intensity: see Table 1 . The maximum intensity found was 12 individuals (in Notothenia rossi marmorata). Notothenia rossi marmorata and $N$. gibberifrons proved new hosts.

Location: Mature and juvenile individuals in the second half of small intestine, juveniles also in large intestine.

Dates of findings: February 8 and March 3, 1977 (off South Shetlands); April 2, 1977 (off South Georgia).

Number of individuals examined: 4 mature individuals (off S. Shetlands) 1 mature and 11 juvenile individuals (off South Georgia).

Description (all measurements taken from mature individuals). Oval body measuring $1.31-1.73 \times 0.403-0.575 \mathrm{~mm}$. Cuticle covered with fine spines extending ventrally to about $3 / 4$ and dorsally to the half of body length. Subterminal oral sucker measuring 

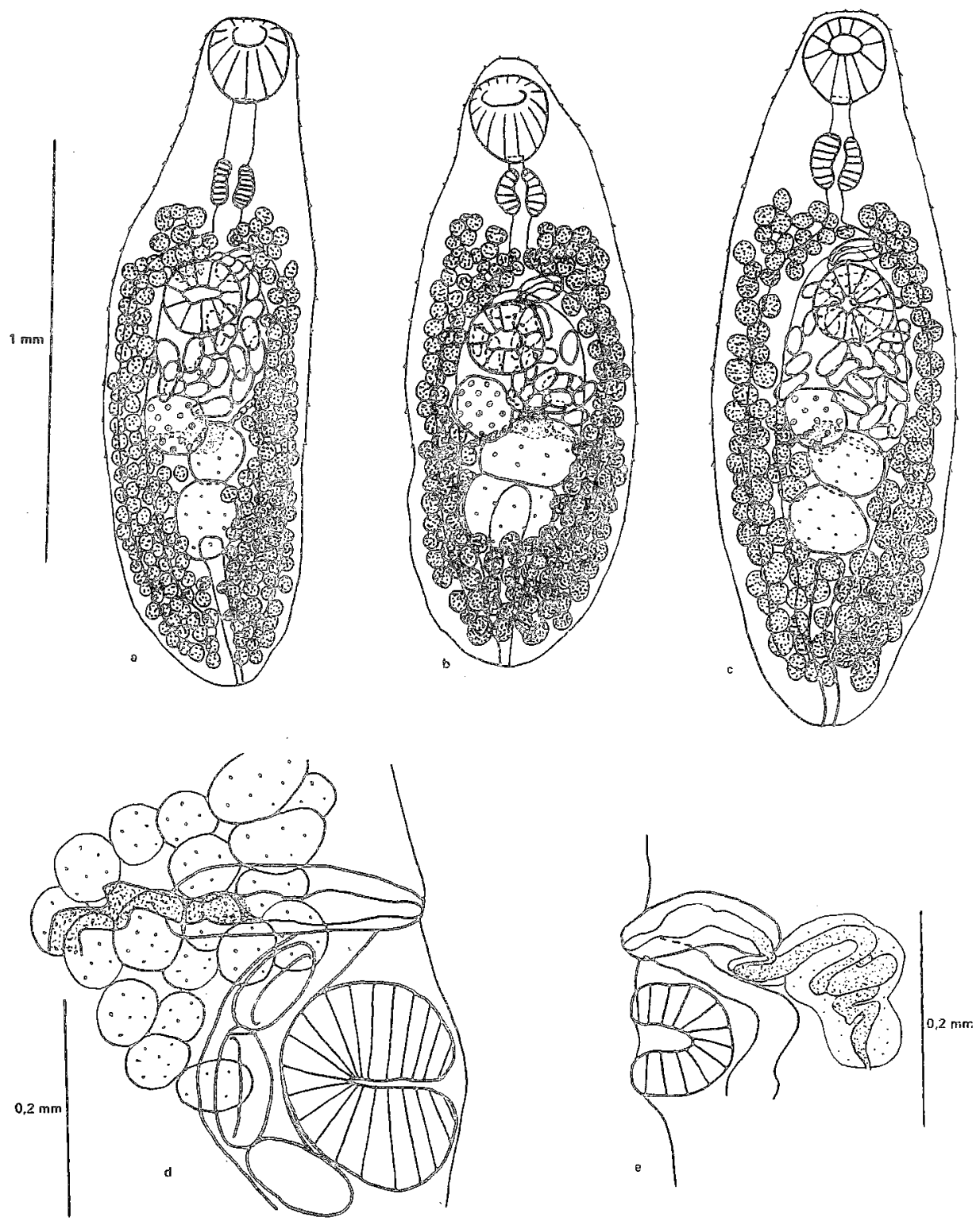

Fig. 1. Lepidapedon antarcticus. a-c. Individuals found off South Shetlands, total (ventral) view: a - an individual from $N_{0}$ gibberifrons, $\mathrm{b}$ - an individual from $N_{0}$ rossi marmorata, $\mathrm{c}$ - an individuas from $N_{0}$ corriceps neglecta. $\mathrm{d}-$ an individual from $N_{0}$ rossi marmorata off South Shetlands, side view: region of bursa cirri covered by vitellaria. $\mathrm{e}-$ an immature individual from $N_{0}$ rossi marmorata oif 
140-220 x 138-210 $\mu \mathrm{m}$. Pharynx dimensions: 87-137 x 91-133 $\mu \mathrm{m}$. Praepharynx well-developed, in some individuals contracted (minimum length of $30 \mu \mathrm{m}$ ), in others clearly longer than pharynx (maximum length of $145 \mu \mathrm{m}$ ). Esophagus 60-90 $\mu \mathrm{m}$ long. Intestine bifurcates just before ventral sucker, caeca extending to the posterior body region. Dimensions of ventral sucker: $130-199$ x 138-193 $\mu \mathrm{m}$. Oral/ventral sucker size ratio of 1:0.91-1:1.04 (mean ratio of 1:0.97); oral sucker size (pharynx length ratio of 1:0.61-1:0.67 (mean of 1:0.64). Ventral sucker centre located at $38-47 \%$ (mean of $43 \%$ ) of body length.

Ovary situated ventrally at the right side of the body behind ventral sucker. Ovary dimensions: $111-202 \times 105-161 \mu \mathrm{m}$. Testes arranged one behind the other, the anterior one partly covered, at dorsal side, by ovary. Anterior testis dimensions: $150-217 \times 137-254 \mu \mathrm{m}$; posterior testis measuring $167-233 \times 136-255 \mu \mathrm{m}$. Seminal and vitellary receptacles dorsal relative to ovary and anterior testis. Vitellaria at either body side. Both stripes of vitellaria fuse in the posterior part of the body behind testes and dorsally in the arterior part near esophagus and the area of intestinal bifurcation. Uterus containing a low number (20-30) of eggs is situated before gonads, dorsally relative to ventral sucker. Genital atrium placed befor ventral sucker and to the left from the kody axis. Bursa cirri extends somewhat obliquely towards the dorsal side. Bursa cirri measurements (as measured on a side view of trematodes): 167--235 x 105-125 $\mu \mathrm{m}$. Past bursa cirri and dorsally relative to ventral sucker there is convoluted external seminal vesicle surrounded by a membraneous sac; this region, however, is ill-visible, being obscured by ventral sucker, vitellaria, and eggs in uterus. Eggs measuring $83-130 \times 48-66 \mu \mathrm{m}$. Excretory pore at the end of the body. Excretory vesicle teminates near posterior testis.

Remarks. Two species of the genus Lepidapedon have been described in Antarctic fishes: L. garrardi (Leiper et Atkinson, 1914) and L. antarcticus Byrd, 1963, the latter description only (Byrd, 1963) being considered satisfactory. According to Prudhoe and Bray (1973), the two species differ in egg dimensions and sucker size ratios. Leiper and Atkinson $(1914,1915)$ gave the L.garrardi egg length as $100 \mu \mathrm{m}$, but Prudhoe and Bray (1973) stated the range of $142-170 \mu \mathrm{m}$ for the same individuals and $137-156 \mu \mathrm{m}$ for the newly-found ones. The egg length of L. antarcticus, as measured by Byrd (1963), was $109-148 \mu \mathrm{m}$, the data of Prudhoe and Bray (1973) indicating the range of 95-118 $\mu \mathrm{m}$. Prudhoe and Bray (1973) are of the opinion that Byrd's (1963) data could have been derived from individuals belonging to both species. Those authors indicate the L. antarcticus ventral sucker to be the larger one (the ratio of $1: 1-1: 3$ ), whereas the oral sucker is the larger one in L. garrardi (the ratio of 1:0.7-1:0.96). Those individuals found by the present author occupy an intermediate position with regard to their sucker size ratios and basically correspond with the description of $L$. antarcticus with respect to their egg size. It should be, however, emphasised that the latter character exhibits a variability range larger than that given by Prudhoe and Bray (1973). Great differences in egg sizes occur both between various individuals and between eggs in one individual's uterus. The present author's material showed egg length varying from $83-90 \mu \mathrm{m}$ to $112-130 \mu \mathrm{m}$. 
The author temporarily denotes his material as IJ. antarcticus, although in his opinion $L$. antarcticus and $L$. garrardi are very likely to be the same species.

In Notothenia neglecta and Parachaeniichthys charcoti off South Orkneys, South Shetlands and Melchior Archipelago, Szidat (1965) and Szidat and Graefe (1967) found trematodes which they identified as Lepocreadium trullaeforme Linton, 1940 (sic, L. trullaforme being the name given by Linton (1940)). Both the descriptions and figures given by Szidat (1965; Figs. 10 and 11) and Szidat and Graefe (1967; Fig. 3) fail to show a number of important characters. However, the arrangement of testes as described by Szidat (1965) and Szidat and Graefe (1967) is completely different from that shown by Linton (1940; Figs. 53-56). According to Linton (1940), egg length is larger than ventral sucker diameter, the number of eggs in uterus not exceeding 10. Linton's (1940) materials were collected off the eastern coasts of the USA, The Antarctic trematodes, according to Szidat and Graefe (1967; Figs. 3-14) produce a larger number of eggs, the length of which being clearly smaller than ventral sucker diameter. Basing on the presently-described material the author suggests Lepocreadium trullaeforme sensu Szidat and Szidat and Graefe nec L. trullaforme Linton to be identical with Lepocreadium antarcticus. A part of the author's material was collected in the same region and from the same ( $N$. corriceps neglecta) and related fish species. A final decision as to the specific identification of the tremotedes in question cannot be reached until Szidat's and Szidat and Graefe's materials are re-checked in order to compare the structure of vas deferens.

Elytrophalloides oatesi (Leiper et Atkinson, 1914)

Synonyms: Hemiurus oatesi Leiper et Atkinson, 1914; Parahemiurus oatesi Leiper et Atkinson, 1914); Elytrophalloides merluccii Szidat 1955.

Hosts and invasion intensity: see Table 1. The maximum intensity found was 583 individuals (in Pseudochaenichthys georgianus). P. georgianus, Champsocephalus gunnari, Notothenia corriceps neglecta and $N$. gibberifrons are newly-found hosts.

Location: Stomach. In mass invasion also mouth cavity, gills, pyloric caeca, and proximal small intestine.

Dates of findings: March 1977 (off South Shetlands); April 1-5, 1977 (off South Georgia).

Number of individuals examined: 2279.

Remarks: Morphology of the trematodes is in complete accordance with the literature data (Gibson, 1976; and others). Body size and ecsoma length variable, ecsoma occupying from several per cent to almost half the overall body length. Ecsoma may contain excretory vesicle only or additionally ends of caeca and a part of uterus with eggs.

According to Gibson (1976), E. oatesi is the commonest and most frequently mentioned trematode in the Antarctic, and partly sub-Antarctic, fishes, found mainly in the Notothenioidei and other teleosts. The present author's own data indicate the Chaenichthyidae to be principal hosts, most frequently and most intensively attacked, in the area studied. The parasites are extrememly common off South Georgia (all the 
individuals examined proved infested); their occurrence off South Shetlands seems to be less common.

\section{Lecithaster australis Prudhoe et Bray, 1973}

Hosts and invasion intensity: see Table 1. The maximum intensity recorded was 7 individuals (in Notothenia rossi marmorata). Pseudochaenichthys georgianus is a newly-found host.

Location: small and large intestine.

Dates of findings: March 1977 (off South Shetlands); April 1-5,1977 (off South Georgia).

Number of individuals examined: 19, out of which 11 mature ones were measured.

Description: Size of the South Georgia individuals: $1.78-3.13 \times 0.47-1.09 \mathrm{~mm}$, the largest trematodes being found in Ps. georgianus and Ch. aceratus. The South Shetlands individuals were, on the average, much smaller: $1.32-1.90 \times 0.56-0.72 \mathrm{~mm}$. Oral sucker subterminal, sometimes almost terminal, measuring 176-277 x 104-303 $\mu \mathrm{m}$. Ventral sucker measuring $272-549 \times 348-571 \mu \mathrm{m}$, its centre located at $30-42 \%$ (average of $37 \%$ ) of body length. Oral/ventral sucker length ratio ranges within 1:1.53-1:1.79 (mean of 1:1.64). Pharynx dimensions: $119-192 \times 103-108 \mu$. Oral sucker/pharynx size ratio ranges from 1:0.45 to 1:0.60 (mean of 1:0.52). Esophagus $155 \mu \mathrm{m}$ long at the most, not always visible. Caeca terminate at some distance from body end.

Genital atrium located along the body axis and ventrally relative to pharynx and intestine bifurcation. Hermaphroditic sac measuring 128-324 x 65-123 $\mu \mathrm{m}$ (as measured on laterally arranged individuals) runs dorsally or towards the posterior. Male and female ducts fuse into a hermaphroditic one immediately after entering the sac. Pars prostacica long, ca 3-4 times longer than the sac; it extends dorsally towards the posterior. Seminal vesicle, measuring $230-518 \times 134-253 \mu \mathrm{m}$ lies dorsally relative to ventral sucker, usually at least in part behind it, closer to one or the other side. Testes, measuring 163-464 x 140-482 $\mu \mathrm{m}$, situated ventro-laterally, symmetrically or obliquely, behind ventral sucker. Ovary consists of 4 follicular lobes and lies ventrally directly behind testes. Overall dimensions of ovary are 230-536 x 273-610 $\mu \mathrm{m}$. Receptaculum seminis, hardly visible, extends dorsally to ovary and measures $192-446 \times 126-318 \mu \mathrm{m}$. Vitellarium consists of 7 (seldom of 6 or 8) slightly elongated follicular lobes arranged radially; it is placed directly behind ovary. Total dimensions of vitellarium: $241-733$ x 268-663 $\mu \mathrm{m}$. Uterus, situated dorsally and laterally to gonads and posterior part of ventral sucker, may - in those individuals with the highest number of eggs - surround the first. The terminal portion of uterus extends dorsally relative to seminal vesicle and pars prostatica, and opens to hermaphroditic sac. Eggs numerous. Mature eggs measure 23-30 x 14-20 $\mu \mathrm{m}$, immature eggs being smaller (ca $20 \mu \mathrm{m}$ ).

Excretory pore at the end of the body, some individuals having it on a top of a small protrusion. Excretory system Y-shaped, bifurcating at a point near overy; the branches thus formed extend, in a waving manner, along the body sides closer to the ventral side, 


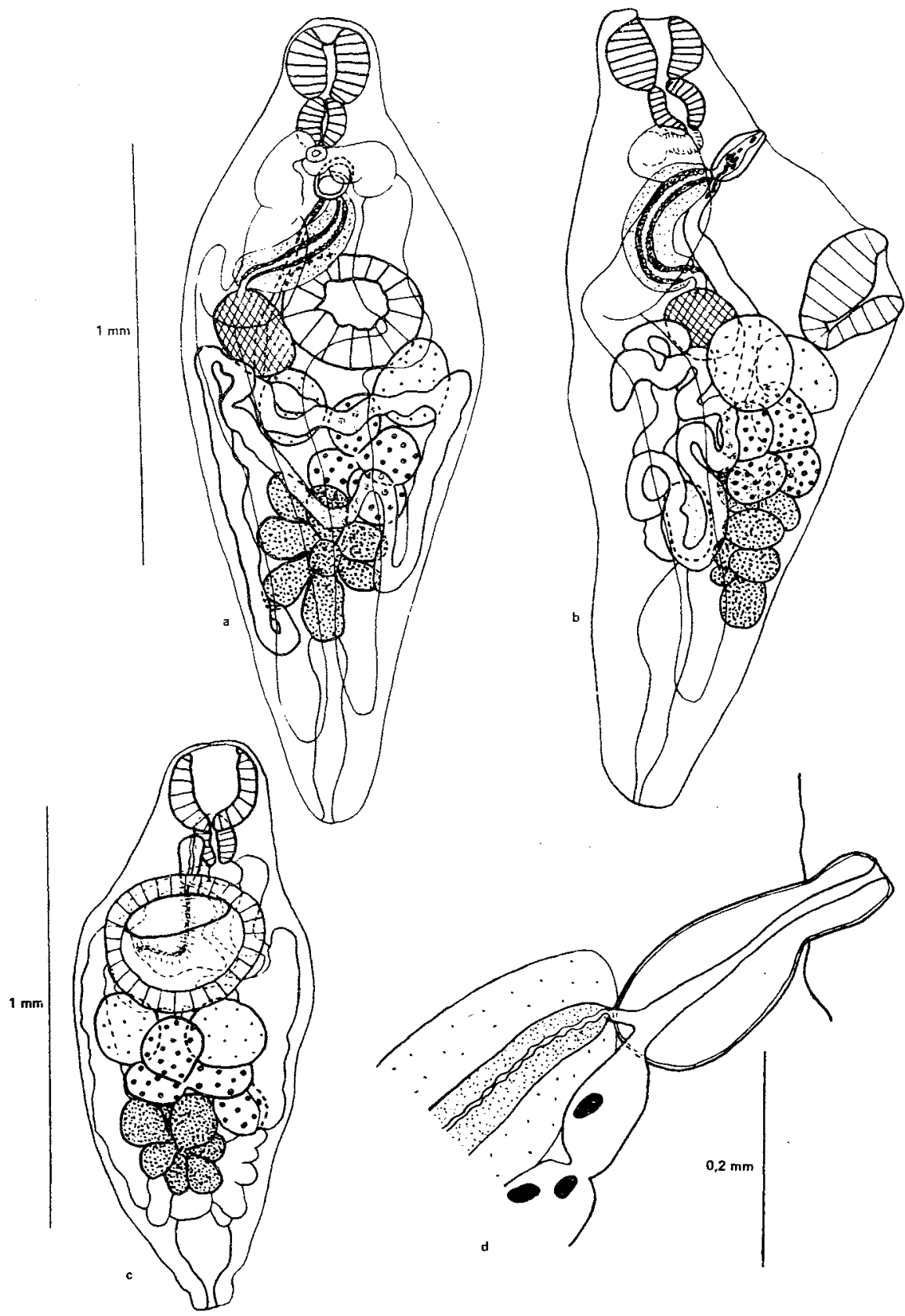

Fig. 2. Lecithaster australis a, b - an individual from N. rossi marmorata off South Shetlands, in dorsal and side view, respectively. $\mathrm{c}-$ a slightly contracted individual from $N$. corriceps neglecta off South Shetlands, ventral view. $\mathrm{d}$ - a juvenile individual from $N$. rossi marmorata off South Georgia, side view of hermaphroditic sac area 
being then directed to the dorsal part before reaching ventral sucker. Their terminal parts were not observed.

Remarks: The parasite's body structure and dimensions correspond to data given Prudhoe and Bray (1973) and Gibson (1976). No differences were observed between the South Georgia and South Shetlands trematodes, except for larger size of those individuals from the first area. Szidat and Graefe (1967) described yet another species, L. macrocotyle Szidat and Graefe, 1967 from off South Shetlands. The present author agrees with Gibson (1976) as to the presumed identity of the two species. The synonymy cannt be, however, fully confirmed in view of smaller eggs $(18 \mu \mathrm{m})$ and a different host (Parachaenichthys charcoti). In order to solve the problem, the typical material must be re-checked or at least materials from a typical host should be obtained.

The parasite is known exclusively from the Antarctica. Prudhoe and Bray (1973) and Gibson (1976) were finding those trematodes in various Notothenioidei of the Kerguelen sub-area and the South Georgia province. The region off South Shetlands is the only area known to house those parasites in the subcontinental province.

Genolinea bowersi (Leiper et Atkinson, 1914)

Synonyms: Aponurus bowersi Leiper et Atkinson, 1914; Genolinea leiperi Byrd, 1963; Genarches lintoni Szidat et Graefe, 1967; Derogenes parvus Szidat, 1950 sensu Szidat 1965 nec sensu 1950.

Hosts and invasion intensity: see Table 1. The maximum intensity found was 96 individuals (in N.rossi marmorata). Notothenia gibberifrons, N. nudifrons, Pleurogramma antarctica, Parachaenichthys georgianus and Chaenocephalus aceratus are newly-found hosts.

Location: stomach.

Number of individuals examined: 426.

Description: Body dimensions: 1.11-2.02 x 0.285-0.579 mm. Dimensions of subterminal oral sucker: $135-183 \times 143-208 \mu \mathrm{m}$; dimensions of ventral sucker $214-198 \times 213-320 \mu \mathrm{m}$. Oral/ventral sucker size ratio $1: 1.35-1: 1.78$ (mean of $1: 1.54$ ). Ventral sucker centre at $27-42 \%$ (35\% on the average) of body length. Pharynx dimensions: $71-119 \times 87-127 \mu \mathrm{m}$. Oral sucker/pharynx size ratio is $1: 0.55-1: 0.72$ (mean of 1:0.63). Esophagus short, $55 \mu \mathrm{m}$ long at the most. Caeca extend to the posterior body region.

Genital atrium near the body axis just behind pharynx. Hermaphroditic sac curved bow-like, measuring 128-199 x 54-90 $\mu \mathrm{m}$ (as measured on laterally arranged individuals). The sac may be retracted into the body; sinus-organ sometimes everted. Just behind the sac extends pars prostatica passing into long and coiled seminal vesicle situated dorsally relative to ventral sucker. Anterior and posterior testes, measuring 107-204 x 104-280 and 128-205 x 145-277 $\mu \mathrm{m}$, respectively, are situated obliquely just behind ventral sucker. Two vitellaria arranged one behind the other, sometimes slightly obliquely, just behind ovary. Dimesions of anterior and posterior vitellaria are $83--212 \times 153-321$ and $79-162 \times 134-250 \mu \mathrm{m}$, respectively. Receptaculum seminis 
measuring $110-250 \times 73-278 \mu \mathrm{m}$ located at the dorsal side. The region of ootype and Mehlis glands between ovary and anterior vitellarium. Uterus, at first running towards the posterior body region, past vitellaria turns to the anterior and opens into hermaphroditic sac. At its base uterus fuses with male duct to form hermaphroditic duct. Eggs very numerous, measuring 33-39 x 15-18 $\mu \mathrm{m}$. Excretory pore at the end of the body.

Remarks: G. bowersi was found to occur in all the Antarctic provinces (Leiper and Atkinson, 1914, 1915; Byrd, 1963; Szidat, 1965, Szidat and Graefe, 1967; Prudhoe and Bray, 1973). These parasites are presumably more common than it has been generally thought. The trematodes attach themselves tightly to fish stomach walls, becoming thus difficult to be seen against this background. Therefore - when collected in the field by non-helminthologists as is frequently the case during various Antarctic expeditions - they. could have been easily overlooked.

Gonocerca phycidis Manter, 1925

Synonym: Gonocerca trematomi Byrd, 1963

Hosts and invasion intensity: see Table 1. The maximum intensity found was 9 individuals (in Pseudochaenichthys georgianus). Ps. georgianus and Parachaenichthys georgianus are the newly-found hosts.

Location: stomach, mouth cavity, gills.

Dates of findings: March 4, 1977 (off South Shetlands); April 1-5, 1977 (off South Georgia).

Number of individuals examined: 23, out of which 14 were measured.

Dimensions: Body size 2.69-6.34 x 0.56-1.10 mm; orae sucker $320-600 \times 340-630 \mu \mathrm{m}$; pharynx $120-210 \times 120-220 \mu \mathrm{m}$; ventral sucker $470-880 \times 490-900 \mu \mathrm{m}$; ovary $250-510 \times 240-460 \mu \mathrm{m}$; right vitellarium $240-520 \times 180-380 \mu \mathrm{m}$; left vitellarium $270-530 \times 200-420 \mu \mathrm{m}$; anterior testis $280-840 \times 350-720 \mu \mathrm{m}$. Distance between genital pore and seminal vesicle proximal end (as measured on laterally arranged trematodes) 350-950 $\mu \mathrm{m}$. Breadth of seminal vesicle $110-300 \mu \mathrm{m}$.

Situation of ventral sucker centre: $55-69 \%$ (59\% on the average) of body length. Oral sucker/pharynx size ratio 1:0.27-1:0.36 (mean of 1:0.33); oral/ventral sucker size ratio $1: 1.31-1: 1.65$ (mean of $1: 1.46$ ).

Remarks: The trematodes body structure and dimensions correspond to the literature data collected from Antarctic and New Zealand individuals (Manter, 1954; Byrd, 1963; Prudhoe and Bray, 1973; Gibson, 1976). Vitellaria usually follicular, somewhat lobed in some instances and in two cases clearly divided into two lobes, which is indicative of a negligible importance of vitellaria lobation as diagnostic character for the genus Gonocerca. A slightly wider range of egg size variability was observed.

G. phycidis was originally described from the northern hemisphere (Manter,1925); the species is the only trematode in the present author's collection, occurring also beyond the Antarctica and Sub-antarctica. The present is the first finding of G. phycidis off South Shetlands. 

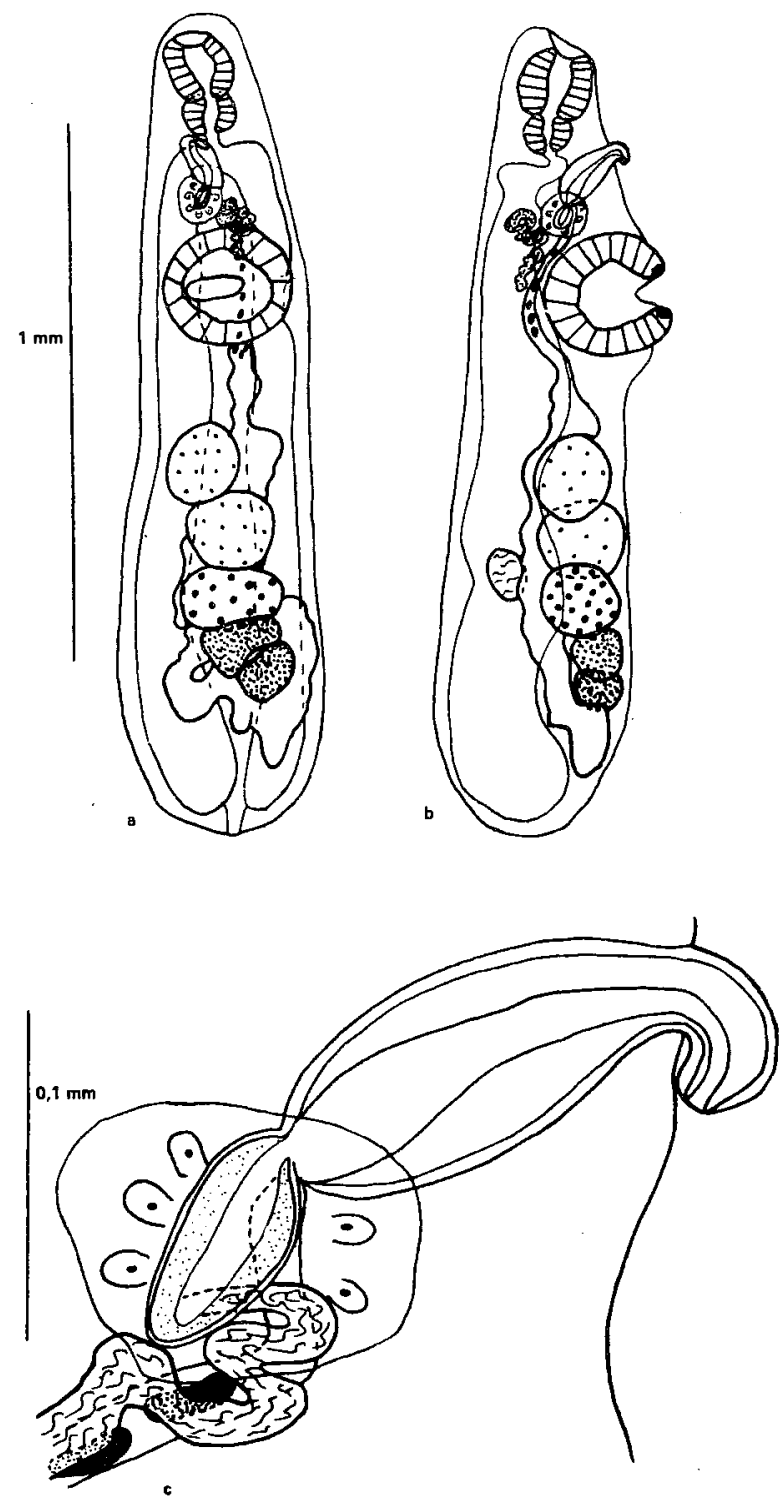

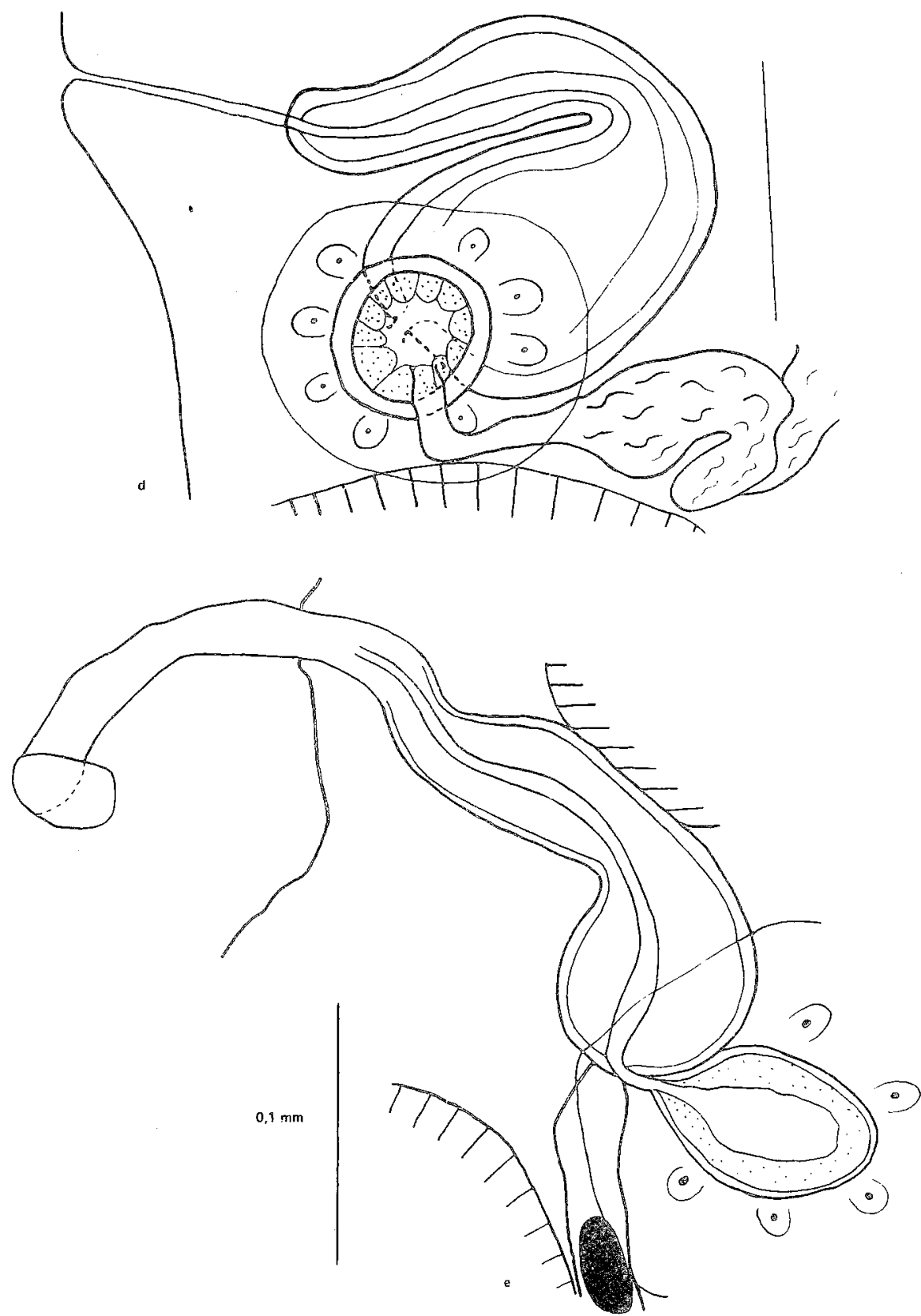

Fig. 3. Genolinea bowersi found off South Shetlands, a, b - an individual from T. bernacchi, ventral and side view, respectively. c - e: side view of hermaphroditic sac area: c -- the individual from T. bernacchi, d - an individual from $N$. rossi marmorata, e - an individual from $N$. corriceps neglecta 

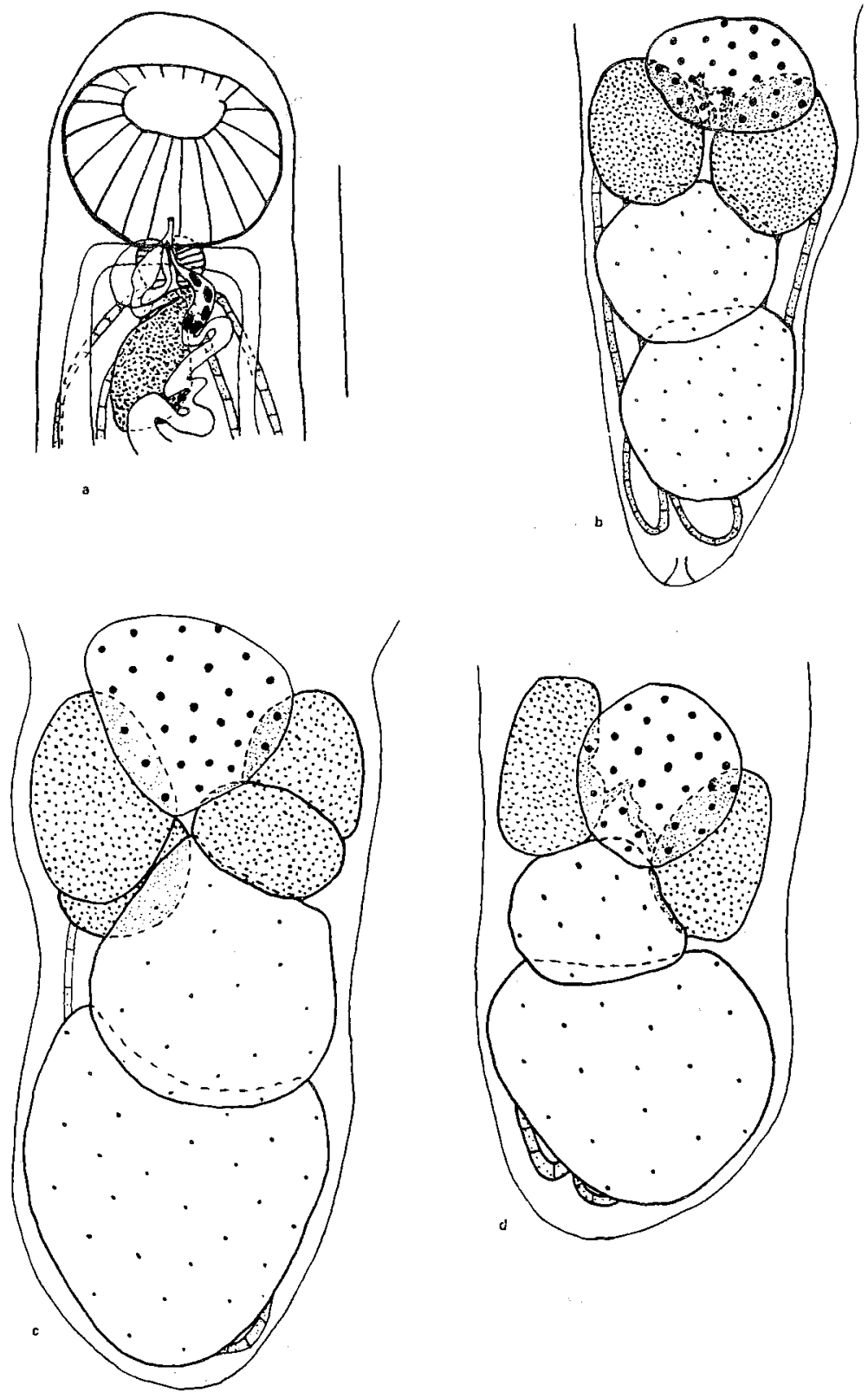

Fig. 4. Gonocerca phycidis, ventral view. a, b: an individual from Par. georgianus off South Georgia: $\mathrm{a}$ - anterior part of the body, b - region of gonads, c, d - region of gonads: c - an individual from Ch. aceratus off South Shetlands, $\mathrm{d}-$ an individual from Ps. georgianus off South Georgia 


\section{RECAPITULATION}

The same 7 trematode species were found in the two areas studied. On the other hand, when the per cent incidence, invasion intensity, and literature data are taken into account, the three following species: L. antarcticus, P. pennelli, and presumably $G$. bowersi seem to be characteristic mainly of subcontinental waters. $I$. georgiensis typical of the South Georgia province, while L. australis is characteristic of both the Kerguelen sub-area and South Georgia province. The distribution ranges of E. oatesi and G. phycidis extend beyond the Antarctica, the two species being seemingly rarer in the subcontinental province than in the remaining ones.

The parasites new for the region off South Georgia were: L.antarcticus and G. bowersi. Off South Shetlands, N. georgiensis, G. phycidis, and L. australis (inasmuch as it differs from L. macrocotyle) were recorded for the first time. E. oatesi predominate off South Georgia, while P. pennelli and G. bowersi are the dominants off South Shetlands.

Three species: E. oatesi, G. bowersi, and G. phycidis occur mainly in stomachs, $P$. pennelli being found primarily in pyloric caeca. Two species, L. antarcticus and L. australis occur mainly in the distal part of small intestine. $N$. georgiensis was found to have been rather evenly distributed along the whole length of intestine.

\section{ACKNOWLEDGMENTS}

The author gratefully acknowledges the help rendered to him by the Head of the Expedition, all the colleagues, as well as by the Captain and crew of MT Dalmor in the collecting of materials; particular thanks are due to Dr C. Żukowski, Mr P. Presler M.Sc., Mr K. Zubek M.Sc., and Mr A. Skowroński, the boatswain. The author wishes to thank Dr J.M. Rembiszewski for identifying the fishes examined.

\section{REFERENCES}

Byrd M.A., 1963: Helminth Parasites of Antarctic Vertebrates. Part I. Digenetic Trematodes of Marine Fishes. - Proc. Helminth. Soc. Wash., 30: 129-148.

Gibson D.I., 1976: Monogenea and Digenea from fishes. - "Discovery” Rep., 36: 179-266.

Kovaleva A.A., Gaevskaja A.V., 1974: Novye predstaviteli Plagioporus (Trematoda, Opecoelidae) ot ryb Antarktiki. - Zool. Zh., 53: 1407-1409.

Leiper R.T., Atkinson E.L., 1914: Helminthes of the British Antarctic Expedition, 1910-1913.Proc. zool. Soc. Lond., 1: 222-226.

Leiper R.T., Atkinson E.L., 1915: Parasitic worms with a note on a free-living nematode. - Nat. Hist. Rep. Br. Antarct. Terra Nova Exped., Zool., 2: 19-60.

Linton E., 1940: Trematodes from fishes mainly from the Woods Hole region, Massachusetts. - Proc. U.S. Nat. Mus., 88: 1-172.

Manter H.W., 1925: Some marine fish trematodes of Maine. - J. Parasit., 12: 11-18.

Manter H.W., 1954: Some digenetic trematodes from fishes of New Zealand.-Trans. R. Soc. N.Z., 82: 475-568. 
Prudhoe S., Bray R.A., 1973: Digenetic trenatodes from fishes. - Rep. B.A.N.Z. antarct. Res. Exped., ser. B, 8: 195-225.

Szidat L., 1965: Estudios sobre la fauna de parasitos de peces antarticos. I. Los parasitos de Notothenia neglecta Nybelin. - Servicio de Hidrografia Naval, Secretaria de Marina, Republica Argentina, Publico H, 910: 1-84.

Szidat L., Graefe G., 1967: Estudios sobre la fauna de parasitos de peces antarticos. II. Los parasitos de Parachaenichthys charcoti. - Servicio de Hidrografia Naval, Armada Argentina, Republica Argentina, Publico H, 911: 1-27.

$\mathbb{Z}$ dzitowiecki K., 1978: Occurence of juvenile forms of Acanthocephala from the genus Corynosoma Lühe, 1904 in fishes off South Georgia and off the South Shetlands (Antarctic). - Acta Ichthyologica et Piscatoria, 8:

Translated: mgr Teresa Radziejewska

\section{PRZYWRY Z PRZEWODU POKARMOWEGO RYB \\ Z OKOLIC POZUDNIOWEJ GEORGII I POLUDNIOWYCH SZETLANDÓW (ANTARKTYKA)}

\section{Streszczenie}

Badano przywry $\mathrm{z}$ przewodu pokarmowego ryb zebrane w czasie Ekspedycji Antarktycznej Instytutu Ekologịi PAN w okresie luty - kwiecieŕ 1977 r. W okolicach Południowych Szetlandów na 46 zbadany ch ryb zarażonych przywrami było 30 (65\%), a w okolicach Południowej Georgii przywry stwierdzono we wszystkich 16 zbadanych rybach. Na obu terenach występowało te same 7 gatunków pasożytów. W okolicach Południowej Georgii gatunkiem dominującym był Elytrophalloides oatesi (Leiper et Atkinson, 1914) występujący głównie w żołądku. W okolicach Południowych Szetlandów najczęstsze były Plagioporus pennelli (Leiper et Atkinson, 1914) zasiedlający głównie wyrostki pyloryczne i Genolinea bowersi (Leiper et Atkinson, 1914), występująca tylko w żołądku. Ponadto stwierdzono jeszcze 1 gatunek żołądkowy, Gonocerca phycidis Manter, 1925, i 3 gatunki jelitowe, Neolebouria georgiensis Gibson, 1976, Lepidapedon antarcticus Byrd, 1963 i Lecithaster australis Prudhoe et Bray, 1973. Spośród powyższych gatunków N. georgiensis, L. australis i G. phycidis nie były dotychczas znajdowane w okolicach Południowych Szetlandów, a 2 inne gatunki, L. antarcticus i $G$. bow'ersi, są nowymi elementami fauny okolic Południowej Georgii.

Na podstawie własnych badań i danych z piśmiennictwa autor sądzi, że 3 gatunki przywr, L. antarcticus, $P$. pennelli i chyba $G$. bowersi, występują głównie w prowincjach subkontynentalnych oraz rzadko w pozostałych prowincjach Antarktyki. Z kolei $N$. georgiensis i L. australis są charakterystyczne raczej dia niższych szerokości geograficznych (subregion Kerguelen i prowincja Południowa Georgia), przy czym $N$. georgiensis znamy tylko z półkuli zachodniej. Zasięg E. oatesi i G.phycidis wykracza poza Antarktykę.

Zamieszczono opisy 3 gatunków, L. antarcticus, L. australis i G. bowersi, oraz uwagi i uzupełnienia dotyczące pozostałych.

К. Эдитовеции

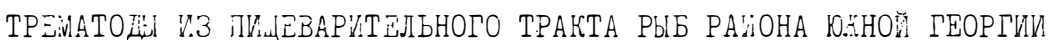

V. ИКННЫХ ШЕТЛАНДСКИХ ОСТРОВ̈ОВ (АНТАРКТИКА)

Резюме

исследованы трематоды из пищеварительного тракта рыб, собранные во времы антарктичєской экспедиции Института Экологии ПАН за период фев- 
раль-апрель 1977 года. В районе южных Шетландских островов среди 46 исследованных рыб, зараженных трематодами, было $30(65 \%)$, а в районе южной Георгии обнаружены трематоды у всех исследованных рыб (16). На обеих территориях находились те же 7 видов паразитов. В районе южон Георгии доминируюцим видом был Elytrophalloides oatesi (Leiper et Atkinson, 1914), выступающий главным образом в желудке. В районе южных Ш̈етландских островов наиболее часто находили Plagioporus pennelli (Leiper et Atkinson, 1914), заселяющий главным образом пилорические отростки, и Genolinea bowersi (Leiper et Atkinson, 1914), выступающй только в желудке. Кроме того, найден ещё один вид, появляющиися в желудке - Gonocerca phycidis Manter, 1925 - и 3 вида, выступаюие в кишечнике - Neolebouria geor giensis Gibson, 1976, Lepidapeon antarcticus Byrd, 1963 и Lecithaster australis Prudhoe et Bray, 1973. Среди вышеуказанных видов N. georgiensis, L. australis $и G$. phycidis до cих пор не находили в районе южных ileтландских островов, а с других вида - L. antarcticus и G. bowersi-являются новыми элементами фауны р-на южной Георгии .

На основании собственных исследований и литературных данных автор предполагает, что 3 вида трәматод - I. antarcticus, P. pennelli и, возможно, G. bowersi - находятся главным образом в субконтинентальных областях, а редко в остальных областях Антарктики. В свою очередь N. georgiensis и L. australi являются характерными для более низких географических широт (субрегион Kerguelen и область южнй Георгии), при этом о N. georgiensis известно только из западного полушария. Диапазон E. oatesi и G. phycidis выходит за пределы Антарктики.

Помещено описание 3 видов - L. antarcticus, L. australis и G. bowersi -, а также заметки и дополнения, касающиеся остальных видов.

Address:

Received: 20 X 1978 r.

Dr Krzysztof Zdzitowiecki

Zakład Parazy tologii

Polskiej Akademii Nauk

Pasteura 3 s.p. 153

00-973 Warszawa 